\title{
Characterisation of two novel types of hexactinomyxon spores (Myxozoa) with subsidiary protrusions on their caudal processes
}

\author{
Sascha L. Hallett ${ }^{1}$, Stephen D. Atkinson ${ }^{1}$, Heidron Schöl ${ }^{2}$, Mansour El-Matbouli ${ }^{1, *}$ \\ ${ }^{1}$ Institute of Zoology, Fish Biology and Fish Diseases, University of Munich, Kaulbachstrasse 37, 80539 Munich, Germany \\ ${ }^{2}$ Institute of Tropical Medicine and Parasitology, University of Munich, Leopoldstrasse 5, 80539 Munich, Germany
}

\begin{abstract}
Two types of hexactinomyxon spores, Hexactinomyxon type 1 nov. and Hexactinomyxon type 2 nov., are reported from freshwater tubificid oligochaetes, Limnodrilus hoffmeisteri and $L$. udekemianus. Spores are triradially symmetrical and comprise a spore body, style and 6 caudal processes. The caudal processes arise from the division of each of the 3 valve cells into an equal pair of projections at the base of the style. One of each pair is fused conspicuously to its nearest neighbour for the initial $1 / 5$ to $1 / 4$ of their total length. Distally, each process possesses subsidiary protrusions which are irregularly distributed and irregularly shaped extensions of the valve cell. Scanning electron microscopy of Hexactinomyxon type 2 nov. revealed that these protrusions are a seamless extension of the valve cell wall which branch distally, occasionally laterally, and terminate in a distinct bulbous structure; they also form the terminus of each process. The small subunit ribosomal DNA gene (18S) of both hexactinomyxon types was amplified through a nested PCR, then digested with the restriction enzymes Dde I and Hha I. The resultant cleavage patterns suggested the presence of 2 forms. Subsequent partial sequencing of $18 \mathrm{~S}$ rDNA confirmed the identification of 2 novel types.
\end{abstract}

KEY WORDS: Actinosporean $\cdot$ Hexactinomyxon $\cdot$ Myxozoa $\cdot 18 \mathrm{~S}$ rDNA $\cdot$ Oligochaete $\cdot \mathrm{SEM}$

\section{INTRODUCTION}

The occurrence of actinosporean parasites in invertebrate hosts has been known about for over a century (Štolc 1899). The number of records of these myxozoans has more than doubled in the past few years with descriptions from all over the world including Canada, Hungary, Ireland and Australia (El-Mansy et al. 1998a,b, Xiao \& Desser 1998a,b, Hallett et al. 2001, Negredo \& Mulcahy 2001).

Fifteen groups of actinosporeans are recognised (Kent et al. 1994, 2001, Lom et al. 1997) of which Hexactinomyxon is one of the least represented. Six types of hexactinomyxon have been described from freshwater tubificid oligochaetes in Germany, Poland, the Czech Republic and Egypt: Hexactinomyxon psammoryctis Štolc 1899; H. hedvigi Janiszweska 1955; Myxobolus pavlovskii (Ruidisch et al. 1991); and Hexactinomyxon types 1-3 (El-Mansy 2001). The life cycle of 1 of these is known: the hexactinomyxon stage of M. pavlovskii, released from the intestinal epithelium of Tubifex tubifex, infects the gill epithelium of silver carp Hypophthalmichthys molitrix (Ruidisch et al. 1991).

Here, we share the finding of 2 hexactinomyxons that differ from previously described forms, both in morphometrics and also in that they possess subsidiary protrusions from their caudal processes. Although modified processes have been documented, for example in Echinactinomyxon (Székely et al. 2002), bifurcation in Raabeia furciligera (Janiszewska \& Krzton 1973) and the raabeia stage of Myxobolus dispar (Molnár et al. 1999), and division into a 3-hooked anchor in the case of Ormieractinomyxon racemosum (Marquès 1984), modifications of the type we report here-complex, subsidiary protrusions or extensions of the valve cells - have not been previously documented. 
Until now, spore morphology has been the prime basis for the taxonomy of actinosporeans (Lom et al. 1997). However, the inclusion of DNA sequence data in the description of actinosporeans has been recommended by several research groups (e.g. El-Mansy et al. 1998a, Hallett et al. 1999, Negredo \& Mulcahy 2001, Hallett et al. 2002). We used PCR and restriction enzymes to confirm our identification of 2 forms of hexactinomyxon, prior to sequencing the $18 \mathrm{~S}$ rDNA gene.

\section{MATERIALS AND METHODS}

Isolation of spores. Live Tubifex oligochaetes were purchased from a Munich pet shop on 22 June and 8 August 2001. In the laboratory, the water associated with the oligochaetes was filtered through a $20 \mu \mathrm{m}$ mesh sieve and the retained material washed into a small petri-dish and examined for the presence of freefloating actinosporeans using a Zeiss Axiovert 25 inverted microscope under phase contrast. After observation of suspended spores, the main worm sample was washed well with fresh tap water, subdivided into 5 to 10 smaller groups in plastic containers and covered with fresh tap water. The following day, water from each container was filtered individually and

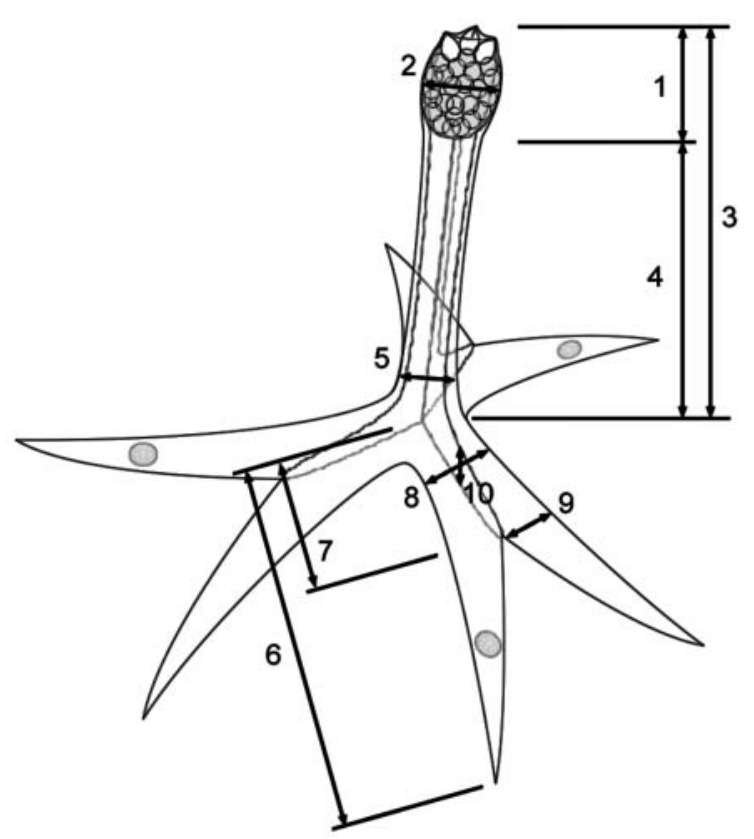

Fig. 1. Generic hexactinomyxon spore with details of parameters measured. 1: Spore body length; 2 : spore body width; 3: spore axis length; 4 : style length; 5 : style width (at base); 6: process total length; 7: process length to bifurcation; 8: process width before bifurcation (across 2 valve cells); 9: process width after bifurcation (1 valve cell); 10: process thickness examined for actinosporeans. Positive samples were further subdivided, then re-examined on subsequent days. Worms were subdivided until approximately 100 to 200 worms remained per positive sample; they were then placed individually into cell-well plates. The wells were examined under a dissection microscope over the following several days until all individuals releasing actinosporeans were separated.

Spores from positive wells were pipetted onto a glass microscope slide and measured under a coverslip using the aforementioned inverted microscope. Spores were also pipetted onto slides, air-dried, fixed, then stained with either Giemsa or Diff-Quik. For scanning electron microscopy (SEM), spores of Hexactinomyxon type 2a (Hex 2a) were fixed in $1 \%$ glutaraldehyde for several days, washed with Sorensen's phosphate buffer ( $\mathrm{pH} 7.4$ ) overnight, dehydrated in a graded acetone series of $10,20,30,40,50 \%$ for 5 min each, then $60 \%$ for $10 \mathrm{~min}, 70,80$ and $90 \%$ for $1 \mathrm{~h}$ each and finally overnight in $100 \%$ acetone. The specimens were then processed in a critical point dryer (BAL-TEC CPD 030), sputter-coated with approximately $12 \mathrm{~nm}$ of gold and examined with a Zeiss digital scanning electron microscope (DSM 950).

Spores are described here in accordance with the guidelines of Lom et al. (1997) though we adopt the term 'spore axis' introduced by Xiao \& Desser (1998a) rather than 'total length', and we use the term 'germ cell' instead of 'daughter cell'. Measurements are of freshly released spores $(n=8$ for Hexactinomyxon type 1, [Hex 1]; $\mathrm{n}=10$ for Hex $2 \mathrm{a} ; \mathrm{n}=10$ for Hex 2b) from 1 host oligochaete (per spore type). Parameters measured are detailed in Fig. 1.

To identify the host oligochaete, the anterior third of each worm was fixed in Bouin's for 3 to $24 \mathrm{~h}$, then transferred to $70 \%$ ethanol. The material was stained in an alcoholic paracarmine solution, differentiated in acid alcohol, dehydrated and cleared through an ethanol-xylene series and finally mounted in Canada balsam. Oligochaetes were identified using characteristics summarised in several standard keys of freshwater Oligochaeta (e.g. Kathman \& Brinkhurst 1998, Timm 1999).

To identify the site of infection, the posterior region was cut into small pieces (1 to $2 \mathrm{~mm}$ ) and fixed in $6.25 \%$ glutaraldehyde overnight, then transferred to phosphate buffer ( $\mathrm{pH}$ 7.2). They were then post-fixed in $1 \%$ osmium tetroxide for $2 \mathrm{~h}$, washed, dehydrated in a graded alcohol series, then embedded in Epon. Semithin sections were stained with Toluidine blue.

Molecular analysis. Hex 1 spores were few in number and were therefore individually pipetted into an Eppendorf tube and the sample frozen; approximately 20 spores were collected for DNA extraction in this way. Hex 2 spores (2 infected hosts releasing spore 
types $2 \mathrm{a}$ and $2 \mathrm{~b}$ ) were collected by placing each host individually in an Eppendorf tube with a small amount of water for several days, after which time the oligochaete was removed and the spore sample frozen. After sampling, oligochaetes were kept alive indefinitely in plastic vials containing sterilised sediment and fresh tap-water, and fed once a fortnight with commercially available dry spirulina.

DNA was extracted from the spores using the QIAamp DNA Mini Kit-Tissue protocol (QIAGEN) according to the manufacturer's instructions except that the samples were resuspended in either $30 \mu \mathrm{l}$ (Hex 1) or $50 \mu \mathrm{l}$ (Hex 2) distilled water (DW).

Initial amplification of the $18 \mathrm{~S}$ small subunit ribosomal DNA gene was achieved using the primers 18e and 18g (Hillis \& Dixon 1991). Primer sequences are detailed in Table 1 . Twenty $\mu \mathrm{l}$ reactions contained $5 \mu \mathrm{l}$ extracted DNA, 4 nmol dNTPs, 10 pmol each primer, $2 \mu \mathrm{l} 10 \times$ Taq buffer, $50 \mathrm{mM} \mathrm{MgCl}_{2}, 1$ unit Taq polymerase and DW. In an Eppendorf Mastercycler Gradient (Eppendorf-Netheler-Hinz) or Primus V1.01 (MWG-Biotech) machine an initial denaturation step of $95^{\circ} \mathrm{C}$ for 2 min was followed by 30 cycles of $95^{\circ} \mathrm{C}$ for $1 \mathrm{~min}, 55^{\circ} \mathrm{C}$ for $30 \mathrm{~s}, 72^{\circ} \mathrm{C}$ for $1 \mathrm{~min}$ and finished with 1 cycle of $95^{\circ} \mathrm{C}$ for $1 \mathrm{~min}, 55^{\circ} \mathrm{C}$ for $30 \mathrm{~s}, 72^{\circ} \mathrm{C}$ for $7 \mathrm{~min}$ with a final rest at $6^{\circ} \mathrm{C}$. The resultant PCR products were combined with gel loading buffer and visualised in a $0.9 \%$ agarose tris-acetate-EDTA buffer (TAE) gel stained with $7.5 \%$ ethidium bromide alongside a 100 bp DNA ladder (GIBCO BRL, Life Technologies) using a CN-TFX Darkroom with UV-Transilluminator TFX-20 (Itf-Labortechnik) and the digital image processed using BioCapt V.97.

A nested PCR using the primers MYX1f (Hallett \& Diamant 2001) and MX3 (Andree et al. 1998) was conducted to amplify sufficient DNA to perform a restriction enzyme digest while maintaining a large fragment of $18 \mathrm{~S}$ rDNA. Reactions of $100 \mu \mathrm{l}$ containing $5 \mu \mathrm{l}$ of the initial PCR product were used in the nested PCR and the products were purified using a QIAQuick PCR Purification Kit (QIAGEN) according to the manufacturer's instructions and the dsDNA concentration measured using an Eppendorf BioPhotometer 6131.

Purified PCR product (1 $\mu \mathrm{g})$ of each actinosporean was digested separately with $1 \mu$ l of 2 different endonucleases, Dde I and HhA I (New England BioLabs), in $50 \mu \mathrm{l}$ reactions and incubated at $37^{\circ} \mathrm{C}$ for $2 \mathrm{~h}$. The resultant digest products were visualised on a $1.5 \%$ agarose TAE gel containing $7.5 \%$ ethidium bromide and run alongside a $100 \mathrm{bp}$ ladder. For comparison with the hexactinomyxon types, an aurantiactinomyxon and a raabeia sample as well as an uninfected Tubifex oligochaete were included in the analysis. These actinosporeans were each released from other oligochaetes isolated during the hexactinomyxon study (authors' unpubl. data).

In preparation for sequencing, different pair combinations of the sequence primers were trialled on the $18 \mathrm{e} / 18 \mathrm{~g}$ template. Initially, a short section of the 1000 bp amplicon produced by MYX1f and ACT1r was sequenced with ACT1fr for all 3 samples (Hex 1, Hex 2a \& Hex 2b) to check further the number of types. Alignment of these fragments in GeneDoc (V2.6.002; http://www.psc.edu/biomed/genedoc) indicated 2 forms. The 18S rDNA of each was then sequenced in 2 parts: the 5' end amplicon generated with MYX1f and ACT1r was sequenced further with MYX1f, ACT1f, and ACT1r; and a 3' end amplicon of $~ 900$ bp generated with ACT3f and MX3 was sequenced with ACT3f, ALL1f, MX3 and ACT2fr. Five $20 \mu$ reactions containing $0.3 \mu \mathrm{l}$ PCR product per reaction were performed, pooled for each sample, purified and the dsDNA concentration measured. The samples were sent to Sequencing Laboratories Göttingen $\mathrm{GmbH}$ for cycle sequencing. Although the primer ACT1r functioned in the PCRs, it failed in the subsequent sequencing reactions of Hex 1. Therefore, for Hex 1 a third amplicon using ACT1f and ACT2fr was produced and a long

Table 1. Primer sequences

\begin{tabular}{lll}
\hline Direction & Sequence & Source \\
\hline Forward & & \\
18 e & 5' CTG GTT GAT TCT GCC AGT 3' & Hillis \& Dixon (1991) \\
MYX1f & GTG AGA CTG CGG ACG GCT CAG & Hallett \& Diamant (2001) \\
ACT1f & GGC AGC AGG CGC GCA AAT TAC CCA A & Hallett \& Diamant (2001) \\
ACT3f & CAT GGA ACG AAC AAT & Hallett \& Diamant (2001) \\
ALL1f & GCG GCT TAA TTT GAC TCA ACA CGG G & Hallett et al. (2002) \\
Reverse & & \\
$18 g$ & 5' CGG TAC TAG CGA CGG GCG GTG TG 3' & Hillis \& Dixon (1991) \\
ACT1fr & TTG GGT AAT TTG CGC GCC TGC TGC C & Hallett \& Diamant (2001) \\
ACT1r & AAT TTC ACC TCT CGC TGC CA & Hallett \& Diamant (2001) \\
ACT2fr & GTA TCC TTC GGA TGT TCG GAC CAG G & Present study \\
MX3 & CCA GGA CAT CTT AGG GCA TCA CAG A & Andree et al. (1998) \\
\hline
\end{tabular}


sequence run made with ACT2fr to compensate for ACT1r. The sequence data were aligned and edited in BioEdit (Hall 1999). A sequence search was conducted using EMBL European Bioinformatics Institute Fasta3 (http://www.ebi.ac.uk/fasta33/).

\section{RESULTS}

Three oligochaetes were isolated, which released 2 types of actinosporean spores belonging to the collective group Hexactinomyxon (Phylum Myxozoa Grassé 1970, Class Myxosporea Bütschli 1881, Actinosporean forms; Kent et al. 1994).

\section{Phenotypic description}

Hexactinomyxon type 1 nov. (Fig. 2, Table 2)

Description. Spore possesses spore body, style and 6 caudal processes (Fig. 2a). Spore body is compact, oval, average length $23 \mu \mathrm{m}$ (range 19.4 to $27.2 \mu \mathrm{m}$; standard deviation 3.3) and width $16.4 \mu \mathrm{m}$ (14.3 to 18.1; standard deviation 1.1) with sporoplasm containing 32 germ cells of diameter $3.6 \mu \mathrm{m}$ (3.4 to 3.9) and 3 almost spherical, non-protruding polar capsules, diameter $4.3 \mu \mathrm{m}$ (3.4 to 5.2; standard deviation 1.3) positioned apically (Fig. 2a, inset). The 3 valve cells fuse to surround polar capsules and sporoplasm to form spore body and elongate style beneath, $53.8 \mu \mathrm{m}$ long (42.7 to 62.2 ; standard deviation 7.2 ), $13.1 \mu \mathrm{m}$ (11.7 to 15.0 ; standard deviation 1.0) wide in middle and $17.2 \mu \mathrm{m}(14.3$ to $23.3 ; 4.2)$ wide at base, with distinct suture line. Spore axis is $76.6 \mu \mathrm{m}$ (69.9 to 82.9; standard deviation 5) long, widens slightly to base where each valve cell divides into 2 equal projections. One of each pair is fused conspicuously to the nearest neighbouring process for $1 / 4(25 \%)(19.3 \mu \mathrm{m} ; 12.9$ to 25.9; standard deviation 4.7 ) of their total length (76.2 $\mu \mathrm{m} ; 59.6$ to 93.2 ; standard deviation 11.9). Width across 2 fused processes $15.9 \mu \mathrm{m}$ (14.2 to 18.1; standard deviation 1.3) and width of single process after suture $9.2 \mu \mathrm{m}$ (7.8 to 12.3; standard deviation 1.3). Processes appear relatively straight at low magnification, taper to a point and possess wispy (Fig. 2b) or bristle-like protrusions. At higher magnification, surface of process appears uneven where subsidiary protrusions are present. Protrusions, irregularly shaped extensions of the valve cell, some simple single extensions, others branched, of varying width, length and thickness, positioned irregularly along distal third of each process. Valve cell nuclei in processes irregularly positioned, diameter $4.95 \mu \mathrm{m}$ (4.7 to 5.2).

Type host: Limnodrilus hoffmeisteri Claparède, 1862

Site in host: intercellular in intestinal epithelium

Source of material: pet shop, Munich, Germany (22 June 2001)

Type specimens: Giemsa and Diff-Quik slides of airdried spores in author's collection

Remarks: spore morphometrics do not correspond with any of the 6 hitherto described hexactinomyxon species/forms, the main difference being the considerably shorter spore axis of our spores (Table 2). Furthermore, the presence of subsidiary protrusions on the caudal processes has not been reported previously. Despite having processes, the spores are negatively buoyant. Only 1 oligochaete out of some 10000 individuals was found to release this spore type. Spores exited the host via the intestinal tract, often in faecal pellets. Spores were released from the worm for several days in the laboratory. The worm was kept alive
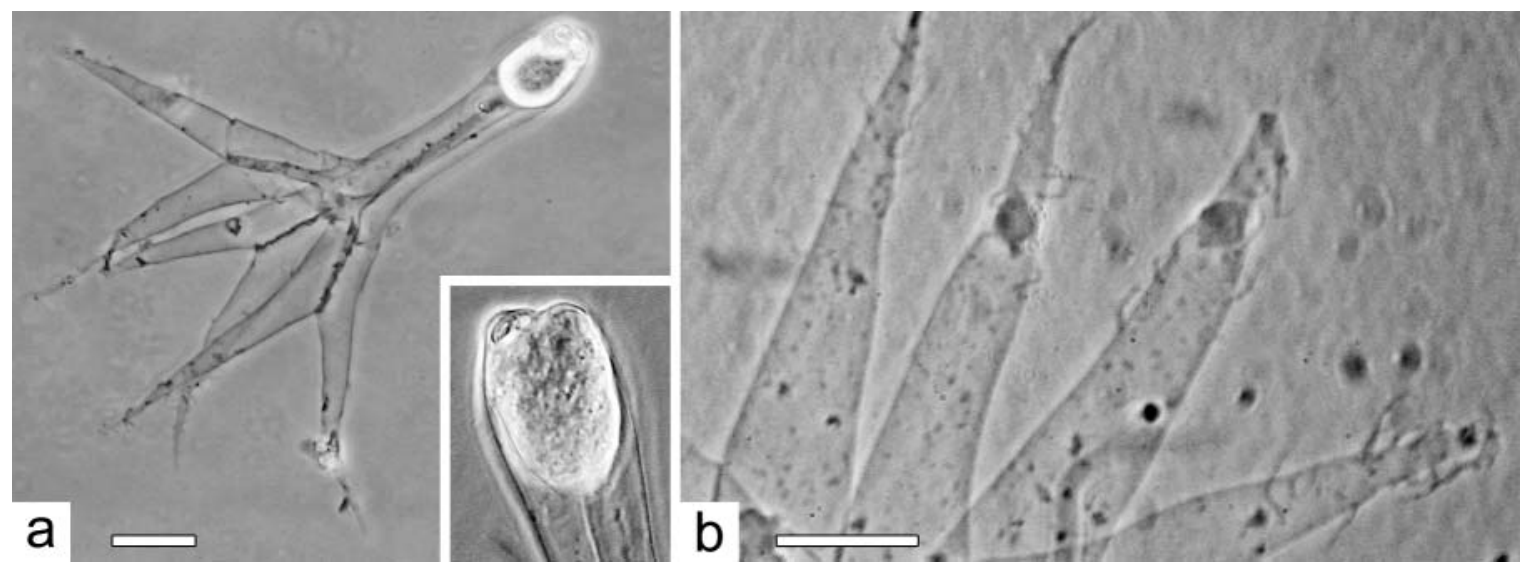

Fig. 2. Hexactinomyxon type 1 nov. (Hex 1) spores. Fresh, unstained, under coverslip. (a) Whole spore with conspicuous valve cell sutures in style and beginning of caudal processes. Scale bar $=20 \mu \mathrm{m}$. Inset: higher magnification of spore body of a second spore. (b) Higher magnification of caudal processes showing wispy subsidiary protrusions. Two valve cell nuclei are visible. 
for a further 12 mo but no further spore release was observed.

Hexactinomyxon type 2 nov. (Figs. 3-6, Table 2)

Description. Spore possesses spore body, style and 6 caudal processes (Fig. 3a). Spore body is prominent, compact, oval, average length $28.6 \mu \mathrm{m}$ (range 25.9 to $31.1 \mu \mathrm{m}$; standard deviation 1.5) and width $17.6 \mu \mathrm{m}$ (15.5 to 18.1; standard deviation 1.1) with sporoplasm containing 32 germ cells (Fig. 3b) and 3 pyriform, apically positioned polar capsules, $6.0 \mu \mathrm{m}$ (5.8 to 6.5; standard deviation 0.4) long and $4.1 \mu \mathrm{m}$ (3.9 to 4.5 ; standard deviation 0.37 ) wide. Extended polar filament length is $37.6 \mu \mathrm{m}$. The 3 valve cells fuse to surround polar capsules and sporoplasm to form spore body and beneath form elongate style, $33 \mu \mathrm{m}$ long (29.8 to 42.7; standard deviation 4.2) and $16.2 \mu \mathrm{m}$ (13 to 19.4 ; standard deviation 1.9) wide at base, with distinct suture line. Spore axis is $61.9 \mu \mathrm{m}$ (58.3 to 68.6; standard deviation 3.4) long, narrows to base where each valve cell divides into 2 equal projections. One of each pair is fused conspicuously to the nearest neighbouring process for $1 / 5$ (19.7\%) (14.1 $\mu \mathrm{m} ; 13$ to 15.5 ; standard deviation 1.1) of their total length (71.7 $\mu \mathrm{m}_{i} 67.3$ to 75.1 ; standard deviation 2.6). Width across 2 fused processes $16.2 \mu \mathrm{m}$ (14.3 to 19.4 ; standard deviation 1.6), width of single process after suture $9.1 \mu \mathrm{m}$ (7.45 to 10.4 ; standard deviation 1.1) and thickness of single process $8.1 \mu \mathrm{m}$ (7.8 to 9.1 ; standard deviation 0.54). Processes appear relatively straight at low magnification and taper distally. The distal half of each process is modified to form numerous thorn-like, outward-pointing protrusions 3.9 to $5.2 \mu \mathrm{m}$ long and $\sim 1.3 \mu \mathrm{m}$ wide. At higher magnification the surface of the distal half of each process appears uneven (knobbly) in the region of the subsidiary protrusions (Fig. 3d-f).

Type host: Limnodrilus udekemianus Claparède, 1862

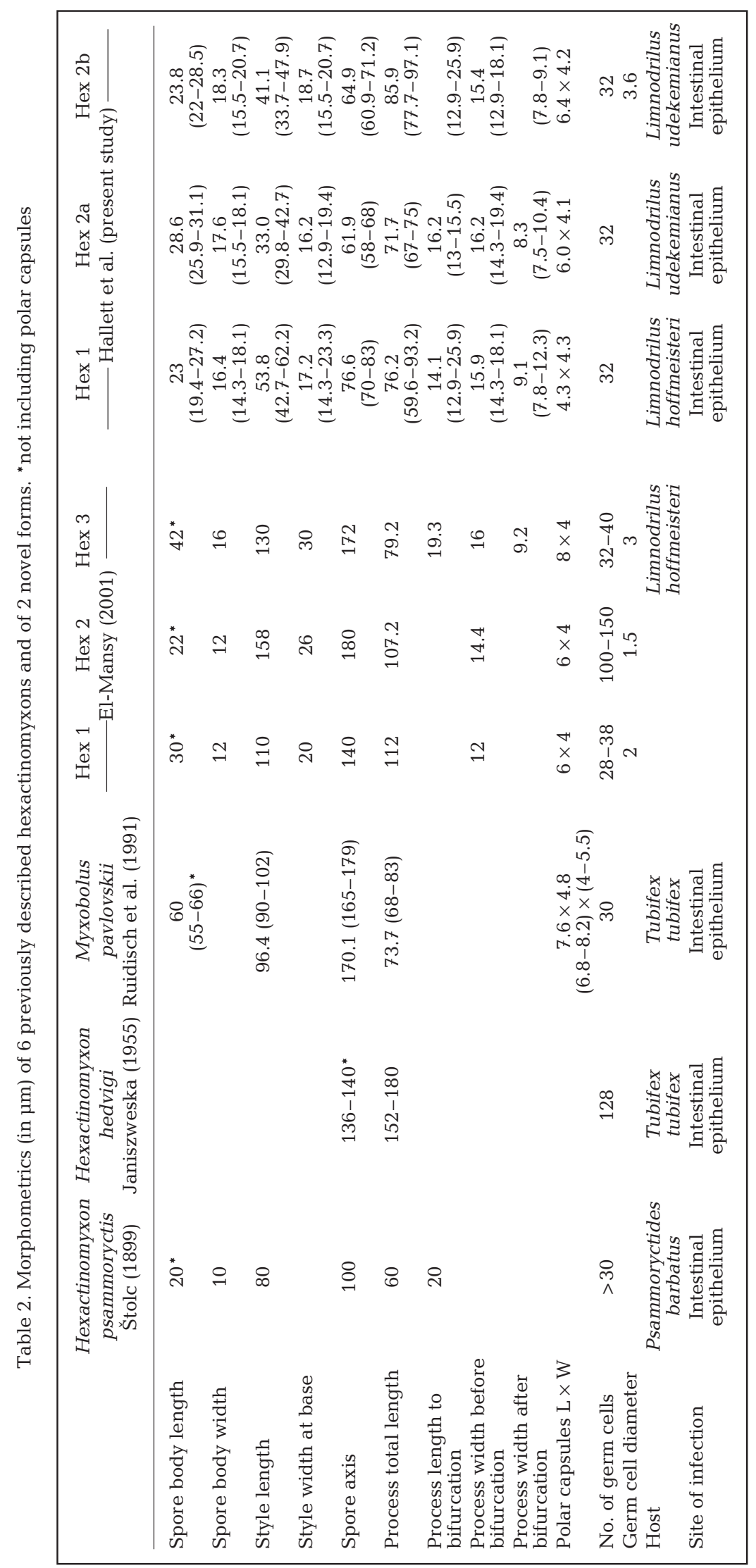



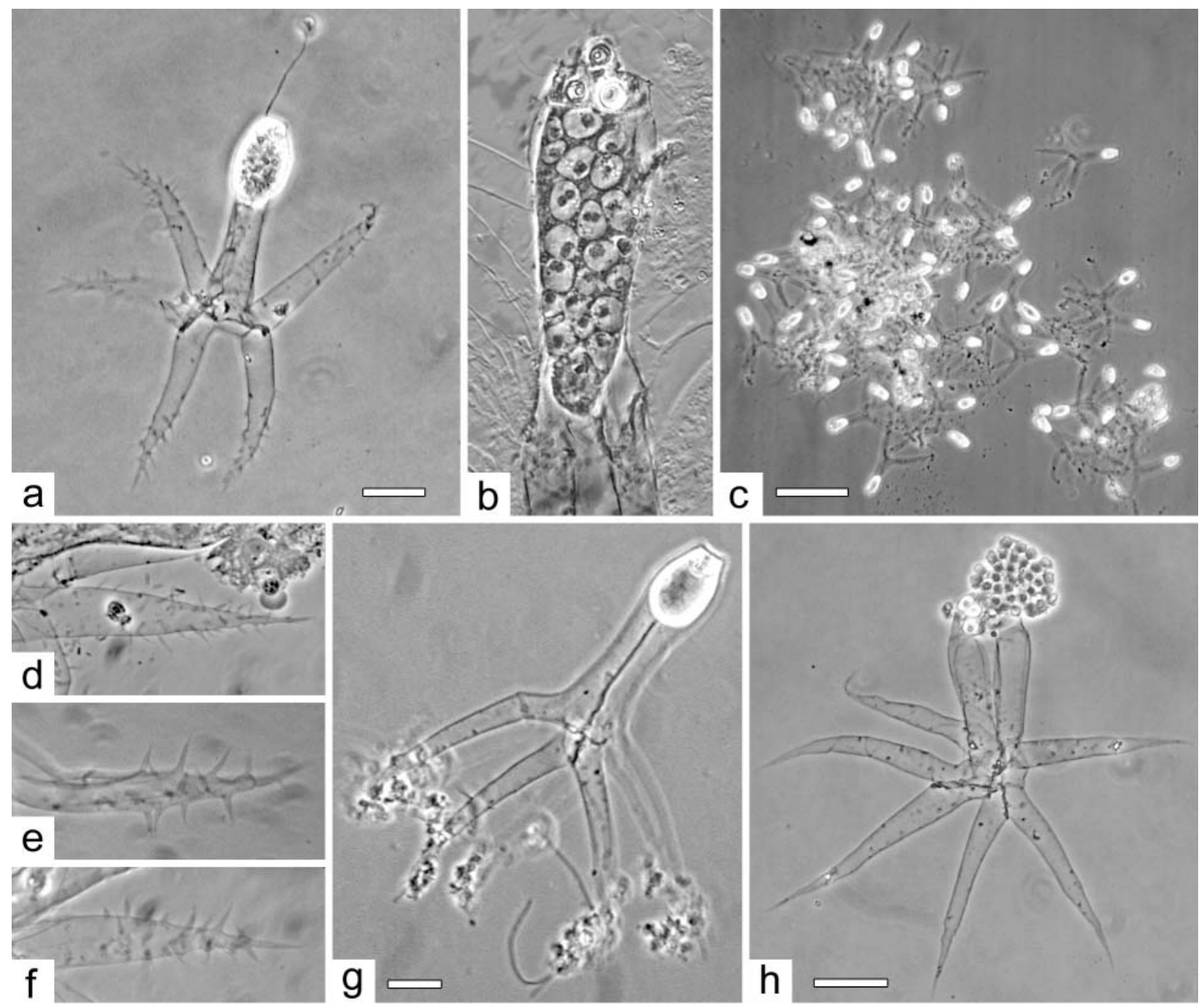

Fig. 3. Hexactinomyxon type 2 nov. (Hex 2) spores. (a) to (g) Hex 2a, (h) Hex 2b. Fresh, unstained, under coverslip. (a) Waterborne spore. One of the 3 polar capsules has extruded its polar filament. Scale bar $=20 \mu \mathrm{m}$. (b) Higher magnification $(\times 400)$ of the sporoplasm and germ cells of a squashed spore showing apparent pairing of the germ cell nuclei. (c) Faecal pellet from host oligochaete containing spores. Scale bar $=100 \mu \mathrm{m} .(\mathrm{d}-\mathrm{f})$ Higher magnification $(\times 400)$ of caudal processes from 3 spores showing variance in protrusions. (g) Spore with debris collected on protrusions of caudal processes. Scale bar $=20 \mu \mathrm{m}$. (h) Squashed spore. Valve cells have separated apically and released the sporoplasm which contains 32 germ cells. Scale bar $=20 \mu \mathrm{m}$

Site in host: intercellular in intestinal epithelium

Source of material: pet shop, Munich, Germany (8 August 2001)

Type specimens: Giemsa and Diff-Quik slides of airdried spores in author's collection

Remarks: Spore morphometrics do not correlate overall with those of other known hexactinomyxons, including Hex 1; the shorter length of the spore axis in our samples being the principal distinguishing feature. Additionally, the ratio of the length of the spore body to length of the style is $1: 2.3$ for Hex 1 but 1:1.2 for Hex 2. Spores were observed in groups associated with faeces of the host oligochaete (Fig. 3c). Fre- quently, debris had accumulated on the subsidiary protrusions (Fig. 3g). A second exemplar of Hexactinomyxon type 2, Hex 2b, was recorded from a second oligochaete out of an estimated 10000 worms in the sample population (Fig. 3h). The morphometrics of this type are detailed in Table 2. Although Hex 2b most closely identifies with Hex $2 \mathrm{a}$, the processes of Hex $2 b$ are longer than those of Hex $2 a$ by almost $20 \%$. However, the ratio of the fused area of the processes (process length to bifurcation) to total process length is similar for both exemplars $(19 \%$ for Hex $2 b$ and $20 \%$ for Hex 2a); and less than that measured for Hex $1(25 \%)$. 
Scanning electron microscopy. SEM resolved the nature of the caudal processes and the valve cell sutures better (Figs. 4-6). The suture lines in the spore surface clearly define the junctions between the 3 valve cells. Each suture extends from the spore apex in a roughly straight line down the spore axis (Fig. 4a), continues past the base for part of the length of 2 cau- dal processes (Fig. 4b), then turns under these processes back towards the spore axis to the centre of the underside of the base (Fig. 4c,d). At the apex of the spore the sutures appear as raised ridges converging in a Y-shape (Fig. 5). In some spores, at each end of this $\mathrm{Y}$ and corresponding to the location of a polar capsule, the sutures are interrupted by an aperture ( 609 $\times$
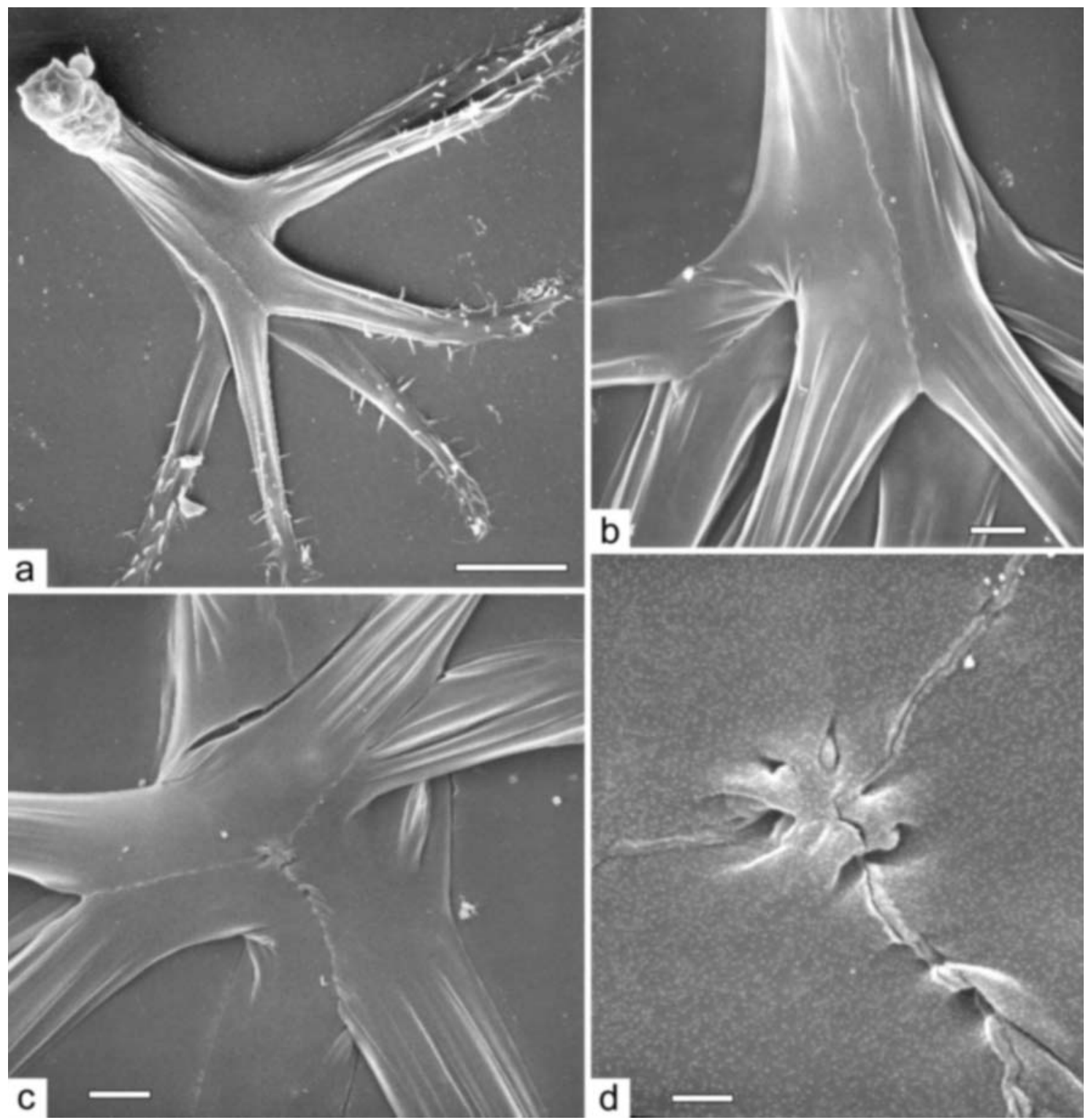

Fig. 4. Scanning electron micrographs of Hexactinomyxon type 2 (Hex 2) spores highlighting the sutures between the valve cells. (a) Side view of a whole spore with prominent suture and protrusions from the caudal processes. Scale bar $=20 \mu \mathrm{m}$. (b) Side view of a spore showing continuation of suture past base of spore axis, between 2 caudal processes for part of their length. Suture only present between every second pair of processes. Scale bar $=5 \mu \mathrm{m}$. (c) Basal view of a spore showing convergence of the 3 sutures. Pairs of the 6 caudal processes are partly fused. Scale bar $=5 \mu \mathrm{m}$. (d) Higher magnification $(\times 9000)$ of the basal junction sutures between the 3 valve cells. Scale bar $=1 \mu \mathrm{m}$ 

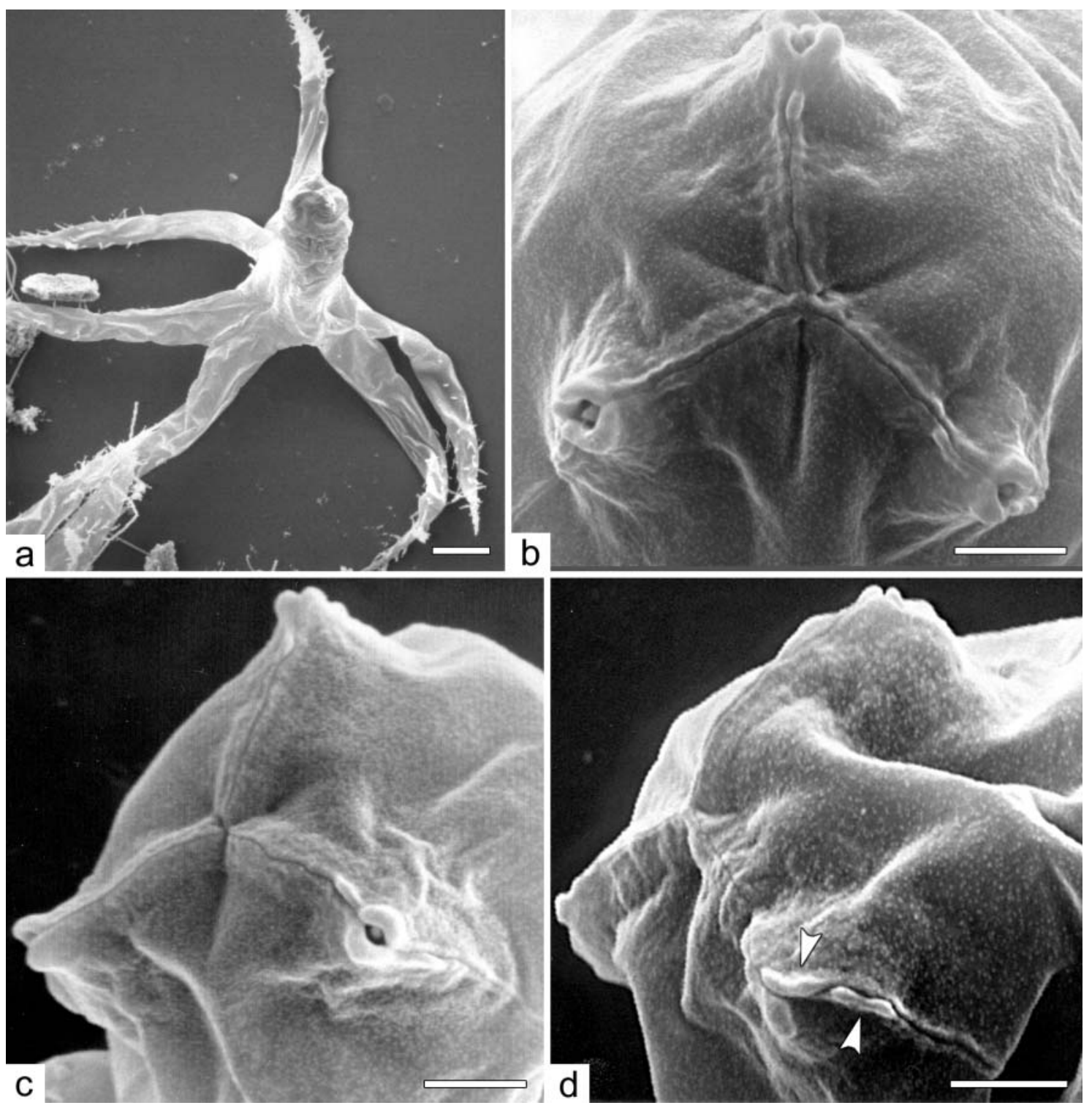

Fig. 5. Spore apex of Hexactinomyxon type 2 (Hex 2) spores using SEM. (a) Oblique view of whole spore. Scale bar = $10 \mu$ m. (b) Apical view showing distinct tri-fold symmetry with prominent sutures between valve cells which form a raised Y-shaped ridge. At each end of the $\mathrm{Y}$ is an aperture through which the tip of a polar capsule is visible. Scale bar $=2 \mu \mathrm{m}$. (c) Oblique view of spore with apertures. Scale bar $=2 \mu \mathrm{m}$. (d) Oblique view of spore lacking apertures. Offset, thickened sutures (arrowheads) in the expected vicinity of an aperture are visible. Scale bar $=2 \mu \mathrm{m}$

$348 \mathrm{~nm})$, the sides of which are thickened, and through which the tip of a polar capsule is visible (Fig. 5b,c); most spores examined lacked these apertures (Fig. 5d).

The caudal processes possess subsidiary protrusions, most of which are angled outwards, toward the tip of the parent caudal process (Fig. 6a). There is no apparent boundary between the valve cell proper and these protrusions (Fig. 6b). The protrusions appear irregularly branched and sub-divided, particularly distally, occasionally laterally (Fig. 6c,d). All sub-divisions terminate in a bulbous structure. The caudal process proper does not taper to a point as suggested by light microscopy, but to a sub-divided and bulbous terminus (Fig. 6e,f).

\section{Genotypic description}

The nested PCR using the primers MYX1f and MX3 generated a $1650 \mathrm{bp}$ amplicon for each sample. Digestion of this fragment with the 2 restriction enzymes Dde1 and Hha1 in separate reactions clearly distinguished the hexactinomyxons from the auranti- 
actinomyxon, raabeia and oligochaete samples (Fig. 7). Both enzymes produced similar banding patterns for Hex 1 and Hex 2 although there were slight size differences evident. Dde1 generated 3 main bands of $\sim 610$, 380 and $295 \mathrm{bp}$ for Hex 1 and $~ 620,380$ and $295 \mathrm{bp}$ for Hex 2a and Hex 2b. Similarly, Hha1 generated 805 and $350 \mathrm{bp}$ fragments for Hex 1 but 785 and 370 bp fragments for Hex 2a and Hex 2b. Several less intense bands were also produced in each digest, again only varying between Hex 1 and Hex 2 and not Hex 2a and $2 \mathrm{~b}$.

Because there were only small differences in the digest banding patterns between Hex 1 and 2, a short length of 18S rDNA toward the 5' end was sequenced for all 3 samples. Comparison of this fragment (344 bp: Hex 2, 345 bp: Hex 1; produced with ACT1fr) revealed 9 base differences between Hex 1 and Hex 2 (97\% homology) but no differences between Hex 2a and Hex 2b.
Further sequencing of the $18 \mathrm{~S}$ rDNA enabled $1423 \mathrm{bp}$ of Hex 1 and $1256 \mathrm{bp}$ of Hex 2 to be determined. These partial 18S sequences are available in GenBank, accession numbers AY162271 (Hex 1) and AY162272 (Hex 2). Hex 1 and Hex 2 shared 94.2\% of their nucleotides. The Fasta3 search revealed that of the myxozoans for which there are sequence data available, Hex 1 and Hex 2 were genetically most similar to Myxobolus pavlovskii (91.4\%) and M. basilamellaris $(93.5 \%)$, respectively (Tables $3 \& 4$ )

\section{DISCUSSION}

Hexactinomyxon is one of the least represented groups of actinosporeans despite the original 'species', Hexactinomyxon psammoryctis, having been one of the first 3 actinosporeans described more than a cen-
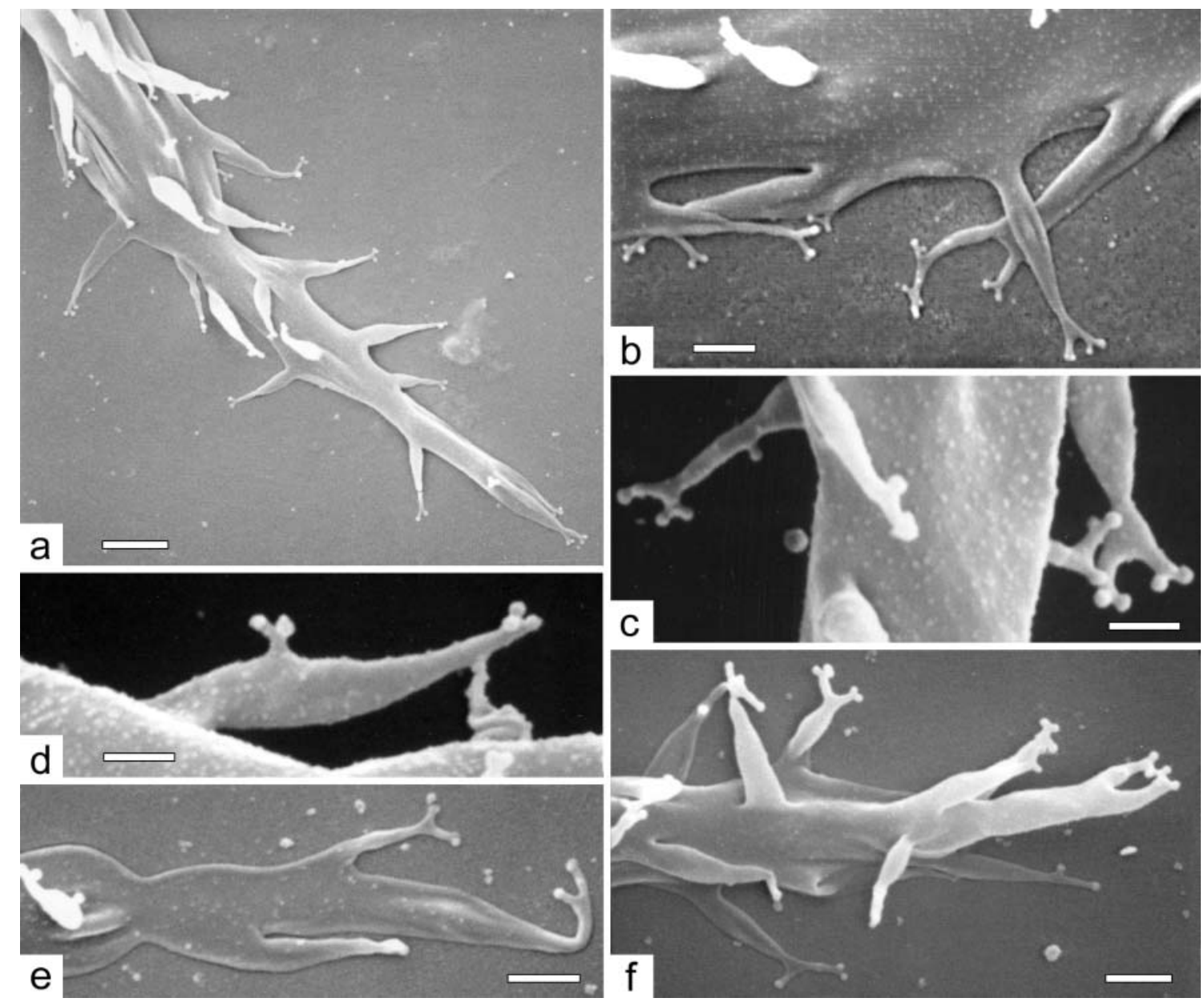

Fig. 6. Subsidiary protrusions of caudal processes of Hexactinomyxon type 2 spores. (a) Distal region of caudal process with numerous outward-directed protrusions. Scale bar $=2 \mu \mathrm{m}$. (b) Seamless interface between main process and protrusions. Scale bar $=1 \mu \mathrm{m}$. (c) Higher magnification $(\times 20000)$ of protrusion subdivisions and bulbous termini. Scale bar $=500 \mathrm{~nm}$. $(\mathrm{d})$ Protrusion with lateral branch. Scale bar $=500 \mathrm{~nm}$. (e) End of main process. Scale bar $=1 \mu \mathrm{m}$. (f) End of main process from a second spore. 


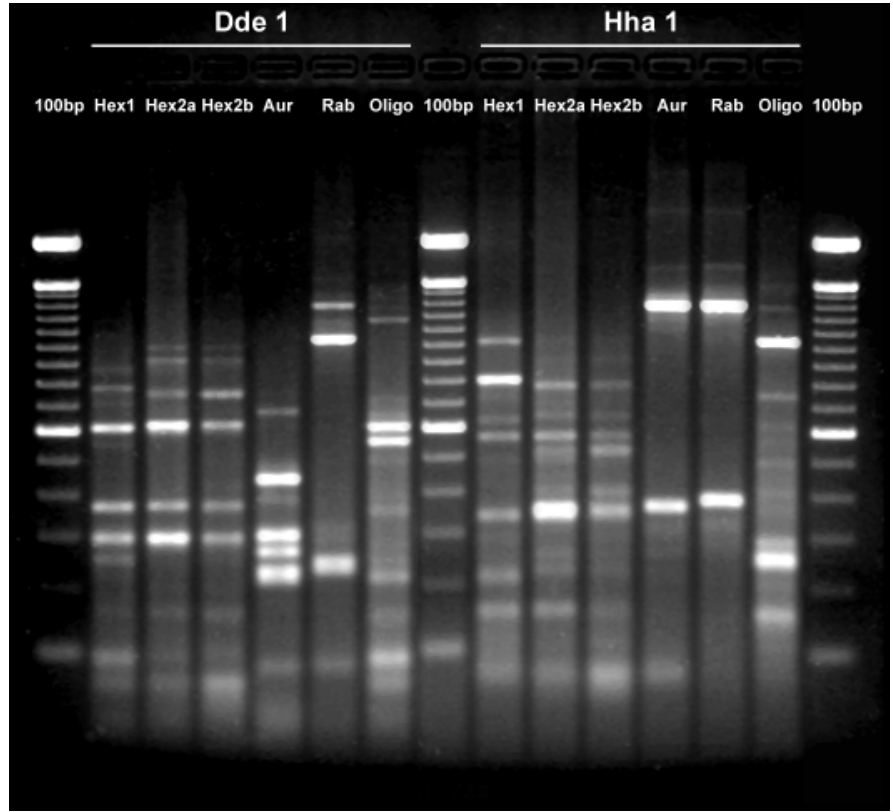

Fig. 7. Riboprint patterns of hexactinomyxon, aurantiactinomyxon, raabeia and oligochaete $18 \mathrm{~S}$ rDNA produced by the restriction endonucleases Dde1 (Lanes 2 to 7 ) and Hha1 (Lanes 9 to 14). $100 \mathrm{bp}=100$ bp ladder; Hex $1=$ Hexactinomyxon type $1 ;$ Hex $2 \mathrm{a}=$ Hexactinomyxon type $2 \mathrm{a} ; \mathrm{Hex} 2 \mathrm{~b}=$ Hexactinomyxon type $2 b$; Aur = aurantiactinomyxon; Rab = raabeia; Oligo $=$ uninfected tubificid oligochaete

tury ago (Štolc 1899). Six forms are now known (see Table 2), half of which were described this past year (El-Mansy 2001); here we describe 2 novel forms. Hexactinomyxon spores are distinguished from all other actinosporeans by their 6 caudal processes which become apparent once the spore inflates after being released from the host. These 6 processes can be considered as modified or bifurcated versions of the 3 pro-

Table 3. Ten myxozoans to which Hexactinomyxon type 1 nov. (Hex 1, 1423 bp) has greatest homology (as determined by Fasta3 search)

\begin{tabular}{|lccc|}
\hline Myxozoan & $\begin{array}{c}\text { Accession } \\
\text { no. }\end{array}$ & $\begin{array}{c}\text { Sequence } \\
\text { size (bp) }\end{array}$ & $\begin{array}{c}\% \\
\text { similarity }\end{array}$ \\
\hline Myxobolus pavlovskii & AF507973 & 1578 & 91.4 \\
M. martini & AF186836 & 778 & 91.3 \\
M. algonquinensis & AF186835 & 1988 & 90.8 \\
M. bramae & AF507968 & 1580 & 90.7 \\
M. basilamellaris & AF507971 & 1592 & 90.4 \\
M. macrocapsularis & AF507969 & 1577 & 90.3 \\
M. siddalli & AF186840 & 801 & 89.9 \\
M. impressus & AF507970 & 1577 & 89.1 \\
M. bibullatus & AF378336 & 2025 & 86.6 \\
Thelohanellus hovorkai & THO133419 & 710 & 86.5 \\
& & & \\
\hline
\end{tabular}

cesses present in other actinosporean groups. The hexactinomyxon spores we isolated differ from all previously described forms morphometrically, and also in that they possess subsidiary protrusions from their caudal processes.

The caudal processes of actinosporeans are generally simple, smooth-surfaced extensions of the 3 valve cells which taper to a sharp or rounded tip. The 6 caudal processes of hexactinomyxons arise from the division of each of the 3 valve cells into 2 equal parts at the base of the spore axis. Each process is fused laterally for the first part of its length to the nearest process of the neighbouring valve cell. The bifurcation of the valve cells in Hexactinomyxon occurs proximal to the base of the spore axis, which sets this class of modification apart from bifurcations and the like observed in other actinosporeans. In the original description of Raabeia furciligera (Janiszewska \& Krzton 1973) each process is described as bifurcated, although in the description by Marquès (1984) the terminus of each process appears to be branched randomly. The terminus of processes of Ormieractinomyxon racemosum (Marquès 1984) thins and forms a 3-hooked anchor. The processes of the raabeia stage of Myxobolus dispar (Molnár et al. 1999) are bifurcated posteriorly and the main branches have further small bifurcations. Each projection of Echinactinomyxon of Székely et al. (2002) has simple, subsidiary protrusions, terminally.

For the hexactinomyxon forms described here, the distal third of each of the 6 processes is further modified, possessing subsidiary protrusions. Unlike spores of Ormieractinomyxon racemosum whose hooked ends enable several spores to connect together, hexactinomyxon spores were never observed to connect via their subsidiary protrusions. The protrusions were, however, observed to readily collect debris. This debris is the likely cause of the spores' pronounced negative

Table 4. Ten myxozoans to which Hexactinomyxon type 2 nov. (Hex 2, 1256 bp) has greatest homology (as determined by Fasta3 search)

\begin{tabular}{|lccc|}
\hline Myxozoan & $\begin{array}{c}\text { Accession } \\
\text { no. }\end{array}$ & $\begin{array}{c}\text { Sequence } \\
\text { size (bp) }\end{array}$ & $\begin{array}{c}\% \\
\text { similarity }\end{array}$ \\
\hline Myxobolus basilamellaris & AF507971 & 1592 & 93.5 \\
M. macrocapsularis & AF507969 & 1577 & 92.1 \\
M. algonquinensis & AF378335 & 1988 & 91.5 \\
M. martini & AF186836 & 778 & 91.5 \\
M. pavlovskii & AF507973 & 1578 & 91.2 \\
M. bramae & AF507968 & 1580 & 90.7 \\
Sphaerospora molnari & AF378345 & 1876 & 90.6 \\
M. impressus & AF507970 & 1577 & 90.0 \\
M. siddalli & AF186840 & 801 & 89.9 \\
M. dispar & AF507972 & 1578 & 88.9 \\
& & & \\
\hline
\end{tabular}


buoyancy: spores were usually detected in water samples after the substrate had been agitated to suspend less buoyant material. This suggests that the subsidiary protrusions act as debris-anchors to hold most spores down onto the substrate, where presumably they are more likely to encounter their next host.

Under a light microscope, the protrusions of different spores appear as wispy filaments, or as bristles, or thorn-like. SEM reveals an additional level of complexity to these structures. There is no obvious boundary between the protrusions and the parent caudal process, which suggests that they are seamless extensions of the valve cell. Each protrusion branches several times, with each sub-division terminating in a distinct bulbous structure, including the very tip of the caudal process.

SEM also revealed detail of the valve cell sutures. The sutures presented as irregular junctions between the valve cells, which converge in a Y-shape at the apex and base of the spore. At the apex, apertures in these sutures were also visible, corresponding to the location of the polar capsules. Apertures were not present in all spores, even though all of the spores were considered mature since they exited the host naturally. In the only previous study to have used SEM to study actinosporeans, El-Matbouli et al. (1999) showed that the sutures of the triactinomyxon stage of Myxobolus cerebralis also form a Y-shape at the apex of the spore with 3 apertures over the polar capsules. They observed that these apertures allowed extrusion of the polar filaments. The apertures we observed in hexactinomyxon are presumably for the same function, although no discharged polar filaments were visible.

Both studies show the continuation of the valve cell sutures from the apex of the spore, past the spore body, to the bottom of the style. In their list of terms, Lom et al. (1997) define the style as the 'small stalk formed in some actinospores by the fusion of the three valvogenic cells below the spore body'. This definition is perhaps somewhat misleading as it suggests that the fusion of the valve cells begins at the base of the spore body, as is also depicted in their diagram. Perhaps the definition should be reordered to read: 'small stalk below the spore body in some actinospores formed by the fusion of the 3 valvogenic cells'. SEM photomicrographs of the triactinomyxon spores of Myxobolus cerebralis show that the sutures between the valve cells turn at the base of the spore axis (El-Matbouli et al. 1999). In hexactinomyxon spores, however, the fusion of neighbouring caudal processes for part of their length gives rise to sutures that continue for some distance past the spore axis before turning to converge under the base of the spore.

El-Mansy (2001) described 3 new forms of hexactinomyxon from Egyptian oligochaetes. In the same study, 3 novel triactinomyxons were also reported. It is significant to note that in the published figures these triactinomyxons all possess prominent sutures in their caudal processes: apparently the extension or continuation of the valve cell suture of the spore axis. This feature was not commented upon by the author, yet appears novel to triactinomyxon forms, and indeed to all actinosporeans reported thus far. In other triactinomyxons, the suture terminates at the base of the spore axis where the processes begin, thereby rendering the processes seamless; a feature evident in most light micrographs and particularly in SEM images of the triactinomyxon stage of Myxobolus cerebralis (El-Matbouli et al. 1999). Indeed, the triactinomyxon forms of El-Mansy (2001) are more similar to hexactinomyxon, since in both cases each valve cell divides into 2 equal parts at the base of the style. In the El-Mansy triactinomyxons, the process remains fused along its entire length to the process of its neighbouring valve cell, whereas in hexactinomyxon spores it is only partially fused (Fig. 8). In this context, hexactinomyxon spores represent an intermediate morphology between existing triactinomyxon forms and the new triactinomyxons of El-Mansy (2001). Indeed, perhaps the novel ElMansy actinosporean forms would be better ascribed a new collective group identity, such as 'Pseudotriactinomyxon'; a name that highlights the more complex nature of what initially appears as a triactinomyxon form. Molecular characterisation of the pseudotriactinomyxon spores would serve to further define this unique spore group and would probably shed more light on their relationship to existing collective groups.

In our study, molecular methods validated the differences in the morphological and morphometrical data recorded for the hexactinomyxons. Riboprinting was used as a preliminary method to determine the number of types present, prior to sequencing. The 2 restriction enzymes Dda 1 and Hha1 were chosen because they are known to generate multiple bands for actinosporean 18S rDNA (Xiao \& Desser 2000) and were already in use in our laboratory. The riboprinting results suggested that Hex 1 and 2 were 2 different spore types, although the band differences were not pronounced, and that the Hex 2 examplars were genetically the same. The use of additional enzymes may have better distinguished between the Hex 1 and Hex 2 samples, however the selection of additional enzymes would have been hit and miss, as at that time no hexactinomyxon sequence had been determined that would have assisted in enzyme selection.

Sequencing was initially conducted on a short 344 bp fragment. This clearly showed that Hex 1 differed from Hex 2a and Hex 2b and that Hex 2a and Hex $2 b$ were identical, confirming the results of the riboprint analysis; further sequencing was performed 


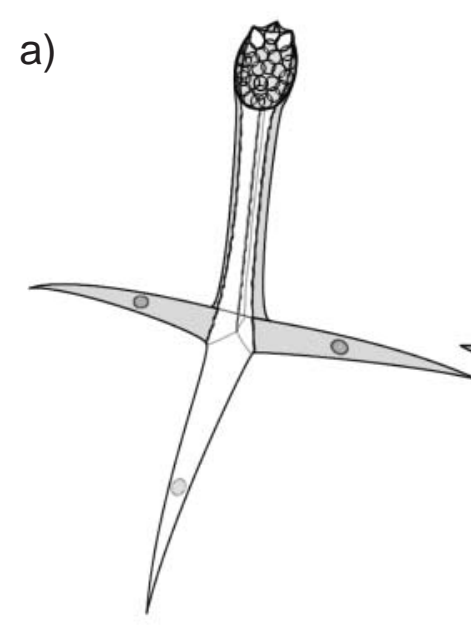

Triactinomyxon

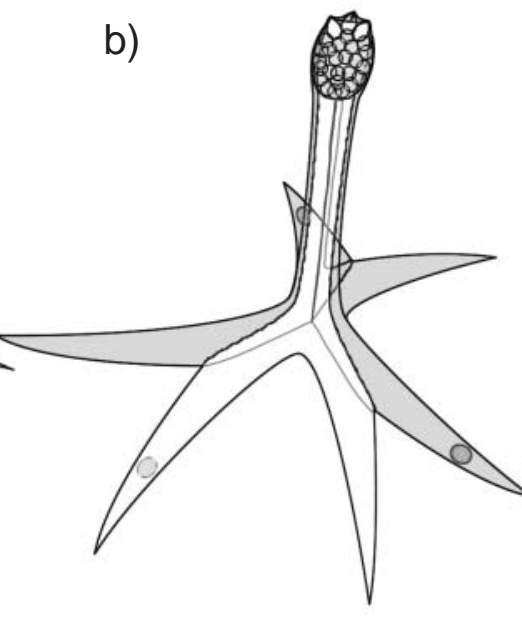

Hexactinomyxon

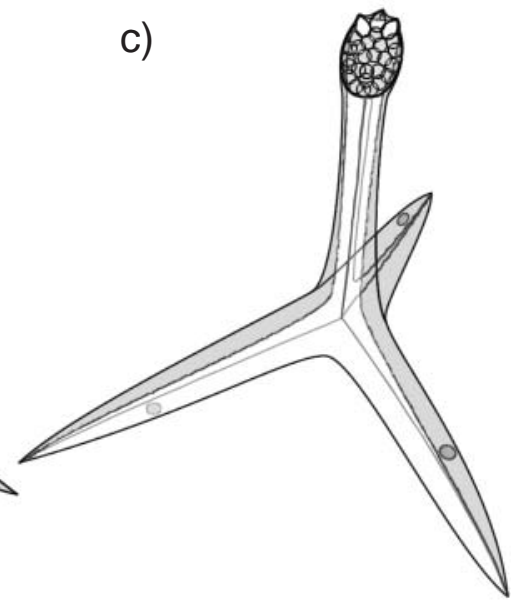

Pseudotriactinomyxon

Fig. 8. Schematic representation of the valve cells and associated sutures in (a) Triactinomyxon, (b) Hexactinomyxon and (c) Pseudotriactinomyxon (Triactinomyxon types of El-Mansy 2001). One of the 3 valve cells is highlighted for each spore. In (a) the sutures extend only to the base of the spore axis; in (b) they continue past the spore base and represent fusion of the initial part of the caudal processes of 2 neighbouring valve cells; in (c) the suture continues for the entire length of the neighbouring valve cells, indicative of their complete fusion

on Hex 1 and Hex 2a only. Comparison of this initial short region with other sequences available in the EMBL invertebrate database gave no match, but showed that the $344 / 5$ bases amplified by the reverse primer ACT1fr contain both conserved as well as variable regions, allowing easy alignment between samples whilst providing informative sites.

The life cycle of neither Hex 1 nor Hex 2 is known. However, the life cycle of 1 other hexactinomyxon has been followed experimentally-that of Myxobolus pavlovskii (parasitising the fish host Hypophthalmichthys molitrix) (Ruidisch et al. 1991). Since the completion of our molecular study, sequence data has become available for $M$. pavlovskii isolated from a different fish host, Aristichthys nobilis. Whilst Hex 1 was most similar to this myxozoan in the database, Hex 2 was more similar to 4 other myxozoans, all Myxobolus spp. (Tables $3 \& 4$ ).

When we first isolated the hexactinomyxon spores, we used morphology and morphometrics to characterise them. It was, however, not immediately clear how many types were present, since several of their features and measurements were similar. The principal differentiating morphometric was the length of the spore axis (a term introduced by Xiao \& Desser [1998] which we prefer to the more ambiguous term 'total length' suggested in the guidelines of Lom et al. [1997]). In order to clarify the number of types present we used molecular methods - riboprinting, supported by the sequencing of a DNA segment containing both conserved and variable regions. We found that this technique enabled the discrimination of the 2 new spore types with confidence.

Acknowledgements. This work forms part of a Research Fellowship to S.L.H awarded by the Alexander von Humboldt Foundation (Germany). We are most grateful to Prof. C. Erséus, Swedish Museum of Natural History, Sweden, for his assistance in the identification of the host oligochaetes. We thank Mrs. Y. Lilliemarck (SMNH) and Mrs. C. Vogt (University of Munich) for assistance with preparation of the worm slides and semi-thin sections, respectively.

\section{LITERATURE CITED}

Andree KB, MacConnell E, Hedrick RP (1998) A nested polymerase chain reaction for the detection of genomic DNA of Myxobolus cerebralis in rainbow trout Oncorhynchus mykiss. Dis Aquat Org 34:145-154

El-Mansy A (2001) First record of actinosporean stages of fish myxosporean parasites (Myxozoa: Myxosporea) in Egypt. J Egypt Soc Parasitol 31:449-465

El-Mansy A, Székely C, Molnár K (1998a) Studies on the occurrence of actinosporean stages of fish myxosporeans in a fish farm of Hungary, with the description of triactinomyxon, raabeia, aurantiactinomyxon and neoactinomyxon types. Acta Vet Hung 46:259-284

El-Mansy A, Székely C, Molnár K (1998b) Studies on the occurrence of actinosporean stages of myxosporeans in Lake Balaton, Hungary, with the description of triactinomyxon, raabeia, and aurantiactinomyxon types. Acta Vet Hung 46:437-450

El-Matbouli M, Hoffmann RW, Schoel H, McDowell TS, Hedrick RP (1999) Whirling disease: host specificity and interaction between the actinosporean stage of Myxobolus cerebralis and rainbow trout Oncorhynchus mykiss. Dis Aquat Org 35:1-12 
Hall TA (1999) BioEdit: a user-friendly biological sequence alignment editor and analysis program for Windows 95/98/NT. Nucleic Acids Symp Ser 41:95-98

Hallett SL, Diamant A (2001) Ultrastructure and small-subunit ribosomal DNA sequence of Henneguya lesteri n.sp. (Myxosporea), a parasite of sand whiting Sillago analis (Sillaginidae) from the coast of Queensland, Australia. Dis Aquat Org 46:197-212

Hallett SL, Erséus C, Lester RJG (1999) Actinosporeans (Myxozoa) from marine oligochaetes of the Great Barrier Reef. Syst Parasitol 44:49-57

Hallett SL, Erséus C, O'Donoghue PJ, Lester RJG (2001) Parasite fauna of Australian marine oligochaetes. Mem Queensland Mus 46:555-576

Hallett SL, Atkinson SD, El-Matbouli M (2002) Molecular characterisation of two aurantiactinomyxon (Myxozoa) phenotypes reveals one genotype. J Fish Dis 25:627-631

Hillis DM, Dixon MT (1991) Ribosomal DNA: molecular evolution and phylogenetic inference. Quart Rev Biol 66: 411-453

Janiszewska J (1955) Actinomyxidia: morphology, ecology, history of investigations, systematics, development. Acta Parasitolog Pol 2:405-437

Janiszewska J, Krzton M (1973) Raabeia furciligera sp. n. (Cnidosporidia, Actinomyxidia) from the body cavity of Limnodrilus hoffmeisteri Claparéde, 1862. Acta Protozool 12:165-167

Kathman RD, Brinkhurst B (1998) Guide to the freshwater oligochaetes of North America. Aquatic Resources Center, College Grove, TN

Kent ML, Margolis L, Corliss JO (1994) The demise of a class of protists: taxonomic and nomenclatural revisions proposed for the protist phylum Myxozoa Grassé, 1970. Can J Zool 72:932-937

Kent ML, Andree KB, Bartholomew JL, El-Matbouli M and 12 others (2001) Recent advances in our knowledge of the Myxozoa. J Euk Microbiol 48:395-413

Lom J, McGeorge J, Feist SW, Morris D, Adams A (1997) Guidelines for the uniform characterisation of the acti-

Editorial responsibility: Wolfgang Körting,

Hannover, Germany nosporean stages of parasites of the phylum Myxozoa. Dis Aquat Org 30:1-9

Marquès A (1984) Contribution à la connaissance des Actinomyxidies: ultrastructure, cycle biologique, systématique. $\mathrm{PhD}$ thesis, Université des Sciences et Techniques du Languedoc, Montpellier

Molnár K, El-Mansy A, Székely C, Baska F (1999) Development of Myxobolus dispar (Myxosporea: Myxobolidae) in an oligochaete alternate host, Tubifex tubifex. Folia Parasitol (Ceske Budejovice) 46:15-21

Negredo C, Mulcahy MF (2001) Actinosporean infections in oligochaetes in a river system in southwest Ireland with descriptions of three new forms. Dis Aquat Org 46:67-77

Ruidisch S, El-Matbouli M, Hoffmann RW (1991) The role of tubificid worms as an intermediate host in the life cycle of Myxobolus pavlovskii (Akhmerov, 1954). Parasitol Res 77: 663-667

Székely Cs, Urawa S, Yokoyama H (2002) Occurrence of actinosporean stages of myxosporeans in an inflow brook of a salmon hatchery in the Mena River System, Hokkaido, Japan. Dis Aquat Org 49:153-160

Štolc A (1899) Actinomyxidies, nouveau groupe de Mesozoaires parent des Myxosporidies. Bull Internat De l'Acad Sci Boheme 22:1-12

Timm T (1999) A guide to the Estonian Annelida. Teaduste Akadeemia Kirjastus (Estonian Academy Publishers), Tallinn

Xiao C, Desser SS (1998a) Actinosporean stages of Myxozoan parasites of oligochaetes from Lake Sasajewun, Algonquin Park, Ontario: new forms of triactinomyxon and raabeia. J Parasitol 84:998-1009

Xiao C, Desser SS (1998b) Actinosporean stages of Myxozoan parasites of oligochaetes from Lake Sasajewun, Algonquin Park, Ontario: new forms of echinactomyxon, neoactinomyxum, aurantiactinomyxon, guyenotia, synactinomyxon and antonactinomyxon. J Parasitol 84:1010-1019

Xiao C, Desser SS (2000) Molecular characterization of myxozoan parasites from Lake Sasajewun, Algonquin Park, Ontario, by riboprinting. J Euk Microbiol 47:85-89

Submitted: August 5, 2002; Accepted: January 28, 2003

Proofs received from author(s): June 11, 2003 